\title{
Benarkah Dokter Spesialis yang Tugas Jaga Pasti Melakukan Pelanggaran Etik Jika Sekedar Menjawab Konsul per Telepon untuk Pertolongan Kegawatdaruratan?
}

\author{
Pukovisa Prawiroharjo ${ }^{\mathrm{I}, 2}$, Radi Muharris Mulyana ${ }^{\mathrm{I}, 3}$, Prijo Sidipratomo ${ }^{\mathrm{I}, 4}$, Agus Purwadianto \\ ${ }^{\mathrm{I}}$ Majelis Kehormatan Etik Kedokteran Pengurus Besar Ikatan Dokter Indonesia \\ ${ }^{2}$ Departemen Neurologi, Fakultas Kedokteran Universitas Indonesia/Rumah Sakit Cipto Mangunkusumo, Jakarta \\ ${ }^{3}$ Instalasi Gawat Darurat RSUPN Dr. Cipto Mangunkusumo \\ ${ }^{4}$ Fakultas Kedokteran Universitas Pembangunan Nasional Veteran Jakarta
}

${ }^{5}$ Departemen Ilmu Kedokteran Forensik dan Medikolegal, Fakultas Kedokteran Universitas Indonesia/Rumah Sakit Cipto Mangunkusumo

\section{Kata Kunci \\ Korespondensi \\ pukovisa@ui.ac.id \\ contact@ilmiah.id \\ Publikasi \\ (C) $2018 \mathrm{JEKI} /$ ilmiah.id \\ DOI \\ I0.26880/jeki.v2iI.I3}

Jaga, spesialis, konsul, gawat, darurat

Tanggal masuk: 27 Februari 2018

Tanggal ditelaah: 1o Maret 2018

Tanggal diterima: II Maret 2018

Tanggal publikasi: I9 Maret 2018
Abstrak Dalam praktik kedokteran sehari-hari, seringkali dokter spesialis dikonsul oleh dokter jaga untuk kasus gawat darurat, dan seringkali pula spesialis tersebut hanya memberikan instruksi per telepon tanpa datang memeriksa pasien. Bila kemudian terjadi kecacatan apalagi kematian pada pasien tersebut, apakah dokter spesialis ini pasti telah melakukan malpraktik etik dan pidana? Tulisan ini akan membahas etika dokter spesialis dalam kegawatdaruratan, khususnya sebagai bagian dari keseluruhan manajemen di Instalasi/Unit Gawat Darurat dan rawat inap di Rumah Sakit, ditinjau dari Kode Etik Kedokteran Indonesia dan berbagai peraturan terkait. Situasi dan kategori tindakan pertolongan kegawatdaruratan yang dimaksud harus benar-benar dipertimbangkan, dan kerja sama yang erat antara dokter spesialis dan dokter jaga diperlukan untuk menjamin keselamatan pasien.

Abstract In daily practice, often specialists are consulted by doctors on duty for emergency cases, and most often these specialists only give per-phone instructions without actually coming and examining the patient. If then the patient suffered disabilities or even death, does the specialist commit sure ethical and criminal malpractice? This paper will discuss the ethics of specialists in emergencies, particularly as part of overall management of Emergency Department and hospital, in terms of Indonesian Medical Code of Ethics and related regulations. The situations and categories of emergency responses should be thoroughly considered, and good cooperation between specialists and doctors on duty is necessary to ensure patient safety.

\section{PENDAHULUAN}

Mulai beredar potongan presentasi sebagai kritik dari sejawat senior yang baik hati dan memiliki latar belakang sebagai spesialis bedah kepada kita semua. Kritik ini menuai reaksi dari banyak sejawat. Potongan presentasi yang menjadi kritik tersebut tertulis sebagai berikut:

"Seorang dokter spesialis yang tugas jaga, yang tidak bersedia datang untuk memeriksa penderitagawat daruratyang dikonsul kepadanya dan kemudian penderita meninggal dunia, maka dokter bukan saja dianggap telah melakukan malpraktik etik, tetapi juga malpraktik pidana, karena kelalaiannya menyebabkan seseorang meninggal dunia. Instruksi dokter mengenai pemeriksaan dan pengobatan per telepon juga dianggap pelanggaran, karena pelayanannya di bawah standar pelayanan medik."

Potongan presentasi ini dimaksudkan kemungkinan sebagai bagian dari penafsiran etika dokter pada kegawatdaruratan, khususnya sebagai bagian dari keseluruhan manajemen di Instalasi/Unit Gawat Darurat dan rawat inap di Rumah Sakit. Tulisan ini membatasi bagaimana relevansi kritik tersebut ditinjau dari Kode Etik 
Kedokteran Indonesia (KODEKI) dan UU atau Peraturan terkait, dan dari sisi tinjauan lapangan yaitu situasi manajemen kegawat daruratan di Rumah Sakit.

\section{HASIL DAN PEMBAHASAN}

\section{Paparan KODEKI tentang Pertolongan Kegawatdaruratan Medik}

Kode Etik Kedokteran Indonesia telah mengatur khusus tentang kegawat daruratan medik pada pasal 17 dengan dinyatakan sebagai berikut: "Setiap dokter wajib melakukan pertolongan darurat sebagai suatu wujud tugas perikemanusiaan, kecuali bila ia yakin ada orang lain bersedia dan mampu memberikannya." Dan salah satu cakupan pasal 17 butir 6 dinyatakan sebagai berikut: "(6) Setiap dokter yang melakukan pertolongan darurat maka kewajiban etis ini mengalahkan pertimbangan-pertimbangan etika lainnya. Dalam menjalankan kewajiban etis ini, dokter tersebut harus dilindungi dan dibela oleh teman sejawat, mitra bestari dan/atau organisasi profesi, pemerintah dan/atau masyarakat."

Dalam penjelasan pasal 17 juga dinyatakan sebagai berikut: "Pertolongan darurat yang dimaksud pada pasal di atas adalah pertolongan yang secara ilmu kedokteran harus segera dilakukan untuk mencegah kematian, kecacatan, atau penderitaan yang berat pada seseorang. Seorang dokter wajib memberikan pertolongan keadaan gawat darurat atas dasar kemanusiaan ketika keadaan memungkinkan. Walau tidak saat bertugas, seorang dokter wajib memberikan pertolongan darurat kepada siapa pun yang sakit mendadak, kecelakaan atau keadaan bencana. Rasa yakin dokter akan ada orang lain yang bersedia dan lebih mampu melakukan pertolongan darurat seyogyanya dilakukan secara cermat sesuai dengan keutamaan profesi, yakni untuk menjunjung sikap dan rasa ingin berkorban profesi untuk kepentingan pertolongan darurat termaksud."

Lalu pada penjelasan cakupan pasal 17 butir 3 dinyatakan sebagai berikut: "Kewajiban pada pasal di atas ini mengamanahkan kepada dokter untuk selalu bersedia melakukan pertolongan darurat kapanpun dan di manapun. Baik di dalam masa dinas ataupun tidak." ${ }^{1}$

\section{Analisis Paparan KODEKI tentang Kegawatdaruratan Medik}

Frase kunci yang relevan dengan kritik yang disampaikan setidaknya ada dua, pertama tentang kesadaran etik bagi seluruh dokter dalam hal melakukan pertolongan kegawatdaruratan, dan kedua adalah klausa kalimat "...kecuali bila ia yakin ada orang lain bersedia dan mampu memberikannya”. Untuk frase kunci pertama, merupakan hal yang tak dapat ditawar lagi bahwa dokter harus menyadari ia memiliki kesadaran tanggungjawab moral yang besar untuk melakukan pertolongan kegawatdaruratan. Bahkan pada situasi ia tidak berdinas saja, tanggung jawab moral itu melekat, sebagaimana dijelaskan pada penjelasan cakupan pasal 17 butir 3 "Kewajiban pada pasal di atas ini mengamanahkan kepada dokter untuk selalu bersedia melakukan pertolongan darurat kapanpun dan di manapun. Baik di dalam masa dinas ataupun tidak.” Tentu apalagi jika dokter tersebut memang saat dinas yang dijadwalkan dan ditentukan RS tempat ia bekerja. Jadi kaidah umumnya, menolak melakukan pertolongan kegawatdaruratan di masa tidak berdinas, apalagi dalam masa berdinas, dapat dikategorikan sebagai pelanggaran etik.

Namun frase kunci kedua tak dapat dipisahkan dari frase kunci pertama, karena disebutkan dalam satu entitas kalimat yang sama, yaitu "...kecuali bila ia yakin ada orang lain bersedia dan mampu memberikannya". Kata "yakin", "bersedia" dan "mampu" perlu digarisbawahi. Penafsiran terbaik pada kata "yakin" dalam pasal 17 yang dimaksud adalah sebagaimana yang termaktub pada penjelasan pasal 17 yang menyatakan "...Rasa yakin dokter akan ada orang lain yang bersedia dan lebih mampu melakukan pertolongan darurat seyogyanya dilakukan secara cermat sesuai dengan keutamaan profesi..." Jadi keyakinan harus dibangun dari sikap cermat dan sesuai dengan keutamaan profesi.

Adapun "bersedia" dan "mampu", hal ini dialamatkan pada orang lain (dokter selain pribadi dokter tersebut). Terkait dengan kritik yang disampaikan mengambil konteks pelayanan 
di UGD atau rawat inap Rumah Sakit, maka paling tepat kata "bersedia" dan "mampu" dialamatkan pada dokter jaga yang dinas di tempat UGD dan rawat inap Rumah Sakit, dan atau dokter spesialis lain yang kebetulan ada di lingkungan RS atau bersedia datang ke RS saat dibutuhkan untuk melakukan pertolongan kegawatdaruratan. Analisis tentang "mampu", tentu saja harus didasarkan pada penilaian sejauh mana kewenangan klinis yang dibangun atas dasar kompetensi profesional, diberikan kepada dokter jaga yang dinas di tempat UGD dan rawat inap Rumah Sakit. Sedangkan analisis tentang "bersedia" ialah kembali ke keyakinan pribadi dokter jaga untuk bersedia mengambil tanggungjawab moral pada suatu pertolongan kegawat daruratan dengan menggantikan kehadiran atau menerima delegasi dari dokter spesialis untuk menjalankan instruksi medis yang diamanahkan kepadanya. Tentu secara umum, pada situasi dokter jaga "tidak bersedia" dan atau "tidak mampu", maka tanggungjawab etik beralih menjadi dipikul SMF Spesialis yang dikonsulkan tersebut.

\section{Paparan UU dan Peraturan lainnya tentang Kegawatdaruratan Medik}

Hingga saat tulisan ini dibuat, belum ada peraturan hukum yang secara spesifik mengatur tentang dokter jaga spesialis dan pendelegasian wewenangnya kepada dokter jaga umum. Walau demikian, dalam UndangUndang Republik Indonesia nomor 29 tahun 2004 tentang Praktik Kedokteran, pasal 51a menyebutkan bahwa dokter harus "memberikan pelayanan medis sesuai dengan standar profesi dan standar prosedur operasional...”. Maka baku rancang standar profesi di Pedoman Praktek Klinis misalnya dan standar prosedur operasional di regulasi internal RS, secara detil perlu menginventarisasi tindakan pertolongan kegawatdaruratan mana saja yang dapat menjadi kewenangan klinis dokter jaga UGD yang sebagian besar adalah dokter umum, tindakan pertolongan atas supervisi, dan tindakan pertolongan yang menjadi wewenang khusus dokter dan SMF spesialis. Pasal 51d memiliki isi yang kurang lebih mirip dengan KODEKI pasal 17 tentang pertolongan gawat darurat, seperti yang telah dibahas di atas. ${ }^{2}$

Peraturan Konsil Kedokteran Indonesia nomor 4 tahun 2011 tentang Disiplin Profesional Dokter dan Dokter Gigi, dalam pasal 3 ayat 2c disebutkan bahwa "mendelegasikan suatu pekerjaan kepada tenaga kesehatan tertentu yang tidak memiliki kompetensi untuk melaksanakan pekerjaan tersebut" adalah pelanggaran displin profesional dokter. ${ }^{3}$

\section{Situasi Lapangan Penanganan Kegawatdaruratan di Rumah Sakit}

Pasien yang datang ke Unit Gawat Darurat atau ruang perawatan darurat lainnya di RS terdiri atas spektrum kasus yang luas, mulai dari kasus tidak berdiferensiasi dengan gejala klinis tertentu (misalnya nyeri, penurunan kesadaran, atau lemas) hingga kasus yang terdiferensiasi jelas di bidang keilmuan tertentu. Pasien dapat berusia ekstrim dari baru lahir hingga usia tua, dengan kondisi kritis hingga tidak ada kegawatdaruratan, atau kasus tunggal sederhana hingga kasus multipel yang rumit.

Tujuan penanganan kegawatdaruratan adalah keselamatan pasien dengan mengatasi kondisi kegawatdaruratan yang diketahui. Pasien perlu ditangani segera dengan waktu respon yang cepat, dan perlu penanganan yang tepat dengan kompetensi yang memadai. Dengan demikian kunci penanganan kegawatdaruratan di RS adalah pembuatan keputusan klinis yang cepat dan tepat dengan didukung sarana penatalaksanaan pasien yang memadai sesuai layanan RS sesuai tingkatan.

Situasi yang mungkin terjadi adalah ketidakmampuan seorang dokter umum untuk melakukan penilaian pasien (asesmen awal) dengan akurat. Hal ini tentu memberikan potensi masalah ketika pelaporan kepada Spesialis saat proses konsultasi. Pada kondisi lain penilaian pasien dapat dilakukan dengan baik akan tetapi ada hambatan komunikasi dengan Spesialis sehingga penatalaksanaan pasien menjadi terhambat. Hambatan komunikasi dapat terjadi akibat tidak terhubung dengan Spesialis atau respon dari Spesialis tidak adekuat baik terlambat atau tidak menjawab. 
Pada RS dengan jumlah dokter spesialis yang berlimpah, tentu dapat membuat kebijakan spesialis yang jumlah kasusnya besar pada RS tersebut agar melaksanakan dinas malam secara standby (jaga langsung di tempat), dan diberikan apresiasi remunerasi yang baik. Pada situasi demikian, tentulah kritik yang disampaikan terkait dokter spesialis tidak hadir dan memeriksa pasien yang membutuhkan pertolongan kegawatdaruratan menjadi tidak relevan, karena sistemnya sudah memadai dan mumpuni untuk menghadirkan dokter spesialis melaksanakan dinas malam secara standby. Keberadaan dokter spesialis yang standby juga dapat menjamin waktu respon yang sesuai dengan kondisi kegawatdaruratan pasien.. Menjadi cita-cita suatu saat seluruh RS di Indonesia dapat menghadirkan sistem seperti ini, sehingga kekhawatiran sebagaimana yang diungkapkan pada kritik yang membangun tersebut, tidak lagi menjadi masalah.

Namun permasalahannya adalah sebagian besar RS di Indonesia mengalami keterbatasan jumlah dokter spesialis, sehingga sebagian besar RS memberlakukan jaga on call untuk dokter spesialis, dan hanya menempatkan dokter umum sebagai jaga standby di UGD dan Ruangan rawat inap. Di sinilah letak permasalahannya saat dokter spesialis yang dinas jaga on call, dihubungi oleh dokter jaga, dan memberi instruksi medis via media yang diperkenankan tanpa datang langsung ke RS memeriksa pasien jika merasa tidak terlalu dibutuhkan.

Adapun media komunikasi antara dokter jaga dan dokter spesialis yang diperkenankan adalah melalui jalur privat, dapat dengan per telepon, atau dengan media sosial jenis privasi tinggi dan terenkripsi end-to-end user sangat baik. Wajib dihindari menggunakan media sosial yang bersifat publik atau dengan fitur privasi dan enkripsi rendah. ${ }^{4}$

Sebagian besar situasi lapangan penanganan kegawatdaruratan di Instalasi/ Unit Gawat Darurat dan di rawat inap di Rumah Sakit di Indonesia secara umum terbagi dua dari sisi waktu, yaitu dinas pada hari dan jam kerja, serta dinas malam (di luar jam kerja) atau hari libur. Dinas pada hari dan jam kerja umumnya terdapat dokter yang berdinas standby penuh bertempat di UGD, biasanya memiliki kualifikasi dokter umum/spesialis dengan persyaratan tertentu, dan karena pada hari dan jam kerja pada umumnya banyak dokter yang berada di lingkungan Rumah Sakit. Sementara dinas malam serta hari libur, tetap ada dokter yang berdinas penuh bertempat di UGD, biasanya dokter umum dengan persyaratan tertentu, dan ada amanah dinas jaga on call (tidak di tempat) bagi dokter-dokter spesialis sesuai keahliannya masing-masing.

Dokter yang jaga UGD baik di dalam maupun di luar hari dan jam kerja, umumnya dibekali suatu kompetensi kegawatdaruratan yang baik. Tentu kompetensi ini ada batasannya. Kompetensi tersebut juga secara umum terbagi dua dalam penerapannya, yaitu kompetensi penilaian terhadap kasus dan kompetensi melakukan tindakan kegawatdaruratan. Kedua jenis kompetensi ini memiliki batasannya pada kewenangan klinis dokter jaga UGD. Pada kasus yang memiliki profil klinis di luar kompetensi penilaian terhadap suatu kasus, dokter jaga UGD umumnya akan menelepon dokter spesialis yang relevan dan kompeten terhadap kasus tersebut. Dokter jaga meminta saran, pendapat, dan instruksi medis dari dokter spesialis yang lebih kompeten.

Sejak dokter spesialis tersebut menjawab, maka hakikatnya kami sependapat dengan kritik tersebut, bahwa akad hubungan dokterpasien telah resmi melibatkan spesialisasi yang relevan. Namun ada satu catatan di sini menurut pengalaman lapangan. Dokter spesialis yang menjawab belumlah tentu yang terjadwal berdinas jaga pada malam/hari libur itu. Alasan teknisnya adalah dokter jaga sulit menghubungi dokter spesialis yang terjadwal jaga pada hari itu. Secara etika, ini baik untuk kedua pihak. Ini perbuatan bernilai etika baik pada dokter jaga UGD karena merefleksikan dirinya sangat peduli dengan pasiennya, dan dalam konteks kegawatdaruratan kebutuhan untuk kesegeraan respon menjadi sangat urgen. Di sisi lain, ini juga perbuatan bernilai etika baik bagi dokter spesialis yang menjawab padahal perbuatan itu dilakukan bukan di hari dan jam dinasnya, dan ini juga merefleksikan nilai kesejawatan yang baik antar sesama spesialis yang ada. Lalu 
bagaimana dan kepada siapa akad hubungan dokter-pasien ini disematkan? Yang jelas, akad tersebut resmi terjadi pada spesialisasi tersebut yang dalam struktur Rumah Sakit, terwakili pada Staf Medis Fungsional/SMF. Mekanisme dan tanggungjawab selanjutnya pada konteks kegawatdaruratan ini ialah diselesaikan melalui mekanisme pada SMF dan atau peraturan RS tersebut.

\section{Klasifikasi Instruksi Medis dari sisi Kewenangan Klinis Dokter Jaga UGD/Rawat Inap dan Implikasi Etiknya}

Kembali kepada situasi di UGD pasca dokter jaga mendapatkan instruksi medis dari dokter spesialis yang kompeten. Dari instruksi medis yang ada, kemudian dapat dibagi tiga kategori menilik dari kompetensi dan kewenangan klinis dokter jaga di UGD yaitu: 1) apakah instruksi medis itu dapat dikerjakan sepenuhnya oleh dokter jaga dan timnya dalam batasan upaya penanganan kegawatdaruratan (harap tidak diterjemahkan dengan penanganan holistik pada pasien), 2) apakah instruksi medis itu dapat dikerjakan penuh oleh dokter jaga dan timnya dalam supervisi, ataukah 3) instruksi medis tersebut kewenangan klinisnya ada pada spesialisasi dan tak dapat didelegasikan kepada dokter jaga, atau jika didelegasikan, dalam konteks penanganan kegawatdaruratan, akan menurunkan kualitas layanan kegawatdaruratan secara signifikan.

Jika kategori instruksi medis tersebut adalah yang pertama, bahwa instruksi medis yang diberikan dapat dikerjakan sepenuhnya oleh dokter jaga dan dalam pendelegasian ini tidak menurunkan kualitas layanan kegawatdaruratan secara signifikan, maka tidaklah melanggar etik bila dokter spesialis yang dikonsulkan per telepon itu tidak secara tatap muka langsung memeriksa pasien. Tanggungjawab secara praktek kedokteran untuk kategori pertama ini sepenuhnya ada pada dokter jaga di UGD, dan oleh karenanya kebijakan paling layak dari RS untuk mengapresiasi tanggungjawab penuh ini ialah memberikan jasa medik atas tindakan tersebut sepenuhnya pada dokter jaga di UGD. Namun, tetap menjadi panggilan etik bagi dokter spesialis yang dikonsulkan tersebut untuk memastikan seluruh instruksi medis yang diberikan memang dikerjakan sesuai standar yang berlaku.

Jika kategori instruksi medis adalah yang kedua, bahwa instruksi medis yang diberikan dapat dikerjakan penuh oleh dokter jaga dan timnya dalam supervisi dokter spesialis yang dikonsul tersebut, maka perlu dicermati kembali bagaimana supervisi yang bertanggungjawab dapat dihadirkan pada situasi ini. Dalam hal ini, kritik tersebut merupakan kritik positif untuk meninjau kembali apakah pola supervisi sudah cukup bertanggungjawab dengan hanya per telepon, bisa jadi hanya sekali itu saja dikerjakan, untuk tindakan medis seperti ini. Maka pendapat kami sebaiknya kategori situasi kedua ini diminimalisasi sejauh mungkin, kalau perlu nyaris tidak ada. Mengapa? Dalam hal ini kami setuju dengan kritik tersebut, karena hal ini menjadi rentan menjadi masalah hukum, disiplin, maupun etika kedokteran. Kerentanan lain juga menyangkut asas keadilan dalam hal pembayaran jasa medik atas tindakan ini dibayarkan atas siapa. Jika dalam supervisi semestinya terbagi secara adil antara dokter jaga dan dokter spesialis yang melakukan supervisi itu, kembali kritik tersebut menekankan seberapa layak dan etis dokter spesialis yang melakukan supervisi dibayar bila supervisi dikerjakan hanya per telepon, dan bagaimana pembagian jasa medik yang dapat dianggap adil?

Bagaimana agar kategori situasi kedua ini diminimalisasi? Tak lain caranya adalah dengan memindahkan sebagian besar kategori kedua ini menjadi kategori pertama, atau diperjelas memindahkan menjadi kategori ketiga. Untuk memindahkan kategori dua menjadi pertama adalah dengan dokter jaga di UGD diberi kewenangan klinis tambahan melalui pelatihan khusus yang dapat diadakan oleh Perhimpunan Dokter Spesialis ataupun internal Rumah Sakit, sehingga melalui sertifikasi yang baik dari pelatihan itu, dapat diperluas kewenangan klinis dokter jaga di UGD melalui peraturan internal RS. Konsekuensi jika terlampau banyak tindakan medis kegawatdaruratan yang ada pada zona kedua ini, maka dalam hal ini kritik tersebut relevan dalam rangka membangun patient safety. Kelalaian medik menjadi tanggungjawab SMF 
spesialis yang bersangkutan, dan selayaknya jika ada masalah di kemudian hari, SMF ini harus mempertanggungjawabkannya secara layak.

Jika kategori instruksi medis adalah yang ketiga, yaitu bahwa instruksi medis yang diberikan memang tidak dapat dikerjakan oleh dokter jaga tersebut, ataupun jika dikerjakan akan menurunkan mutu layanan secara signifikan, maka kritik ini pantas untuk dialamatkan. Dalam keseharian, instruksi medis jenis ini lebih banyak dan lebih relevan ada pada spesialisasi yang "memegang pisau" seperti Bedah, Obstetri Ginekologi, Mata, Telinga Hidung Tenggorokan, dan sebagainya. Kebetulan latar belakang senior yang mengajukan kritik ini adalah spesialis bedah, yang sering ada pada situasi ketiga tersebut, maka kritik pada paparannya yang menjadi viral tersebut lebih banyak merupakan refleksi etika kedokteran pada keseharian praktek yang dilakukannya, dan kritik ini menjadi masukan yang sangat berharga bagi seluruh profesi dokter.

Pada kategori instruksi medis yang hanya dimiliki kewenangan klinisnya oleh dokter spesialis yang dikonsulkan, maka dokter spesialis memang harus datang memenuhi panggilan kegawatdaruratan, memeriksa, dan melakukan tindakan medis kegawatdaruratan tersebut. Ketidakmauan untuk hadir, sebagaimana kritik tersebut, layak untuk dimaknai sebagai bentuk kelalaian medis dan pelanggaran etik dan disiplin, kecuali SMF spesialisasi yang relevan dapat mengompensasi keberhalangan dokter spesialis yang terjadwal jaga tersebut.

Namun tentu saja, untuk menjadi norma etika umum atau bahkan menjadi regulasi di RS maupun hukum praktek kedokteran, maka perlu untuk melihat lebih luas dari keseluruhan praktek kedokteran yang dijalankan seluruh dokter. Bagi sejawat "tak memegang pisau" seperti SMF Anak, Penyakit Dalam, Neurologi, Kardiologi, Pulmonologi, Psikiatri, dan sebagainya yang sebagian besar lebih banyak mengalami situasi pertama dan kedua, tentu kritik ini menyentak dan meresahkan. Tapi kritik ini bermanfaat agar SMF "tak memegang pisau” ini lebih banyak melakukan pelatihan kepada dokter jaga UGD agar memindahkan sebanyak-banyaknya situasi kedua menjadi situasi pertama. Di lain pihak, SMF "tak memegang pisau" perlu membuat regulasi internal yang jelas tentang mekanisme supervisi yang dianggap layak, bertanggungjawab, dan memadai untuk situasi kedua. Seandainya situasinya tidak datang, maka bagaimana mekanisme supervisi yang dapat dianggap layak untuk setiap tindakan medis. Dalam hal ini, maksud kritik tersebut adalah agar dipikirkan kembali apakah hanya per telepon saja dapat dianggap ini adalah supervisi yang memadai? Jika tidak, maka kritik tersebut relevan, dokter spesialis pada situasi kedua memang harus datang ke RS dan memeriksa pasien gawat darurat tersebut sendiri.

\section{Waktu Respon dalam Penatalaksanaan Pasien dan Implikasi Etiknya}

Dalam penatalaksanaan kasus kegawatdaruratan diperlukan waktu respon yang sesuai dengan kondisi pasien untuk mencegah perburukan pada kondisi pasien dan pasien mendapatkan pelayanan kesehatan yang sesuai dengan standar.

Waktu respon sesuai dengan kondisi pasien, apakah pasien dalam kondisi kritis, semi kritis, atau tidak kritis. Berbagai metode triase menjelaskan bahwa pasien dengan kondisi kritis harus mendapat penanganan segera dengan waktu respon 0 menit hingga 10 menit sesuai kasus yang dihadapi, pasien semi kritis 30 menit, dan pasien tidak kritis 1-2 jam. Waktu respon ini ditetapkan berdasarkan kondisi kedaruratan pasien, dalam hal ini kondisi pasien akan memburuk bila tidak dilakukan penanganan segera dalam rentang waktu tersebut. ${ }^{5,6}$

Adapun yang dimaksud dengan respon adalah upaya stabilisasi untuk mencegah kematian atau kecacatan yang masih dapat dihindari, bukan penanganan definitif yang umumnya menjadi ranah bidang keilmuan spesialisasi tertentu. Upaya stabilisasi ini memiliki dimensi waktu dan kompetensi. Yaitu ketika dilakukan dengan waktu respon yang benar dan kompetensi yang sesuai maka prognosis pasien akan baik. Contoh kasus-kasus yang time sensitive misalnya pada pasien dengan stroke akut, infark miokard akut, atau trauma multipel, prognosis pasien akan lebih baik jika 
waktu respon untuk tindakan stabilisasi lebih singkat. ${ }^{7,8}$

Kembali pada situasi ketika dokter jaga IGD melakukan proses konsultasi kepada dokter spesialis. Konsultasi dilakukan pada beberapa kondisi, di antaranya:

1. Dokter jaga IGD sudah melakukan pemeriksaan awal namun belum dapat membuat diagnosis, sehingga memerlukan advis dari dokter spesialis untuk menentukan diagnosis

2. Dokter jaga IGD sudah melakukan pemeriksaan awal dan membuat diagnosis, akan tetapi memerlukan advis dari dokter spesialis untuk terapi definitif dan pelimpahan DPJP kepada dokter spesialis untuk rawat inap

3. Dokter jaga IGD sudah melakukan pemeriksaan awal dan membuat diagnosis, akan tetapi membutuhkan advis segera dari spesialis untuk melakukan terapi dalam rangka stabilisasi pasien di IGD

Beberapa situasi di atas memiliki dimensi kedaruratan yang berbeda. Pada kondisi pertama dan kedua kondisi pasien tidak kritis sehingga faktor waktu respon tidak akan berdampak buruk pada kondisi pasien. Hal yang berbeda pada kondisi ketiga mengingat waktu respon akan menentukan prognosis pasien. Potensi masalah etika akan muncul ketika pasien terlambat ditangani karena komunikasi dan konsultasi ke dokter spesialis mengalami hambatan.

Beberapa cara yang dapat dilakukan untuk menghindari permasalahan etika yaitu:

1. Dokter jaga IGD dibekali kompetensi yang cukup untuk melakukan assessment kegawatdaruratan yang akurat dan mampu melakukan tindakan stabilisasi pasien dan tindakan awal yang time sensitive

2. Memastikan jalur komunikasi yang paten antara dr umum IGD dengan spesialis on call (dengan reward dan punishment misalnya)

3. Sistem untuk menjamin spesialis memberikan assessment dan saran yang akurat (misalnya PPK, clinical pathway)

4. Sistem untuk memastikan pendelegasian wewenang tidak berlebihan atau kurang (clinical privilege yang jelas)
Alternatif lain untuk mengurangi potensi permasalahan etika adalah dengan menempatkan dokter spesialis dengan kompetensi khusus untuk menangani kasus kegawatdaruratan di IGD. Dokter spesialis tersebut berperan sebagai DPJP dalam penatalaksanaan kasus secara medis dalam keadaan darurat terutama pada pasien kritis dan mengerjakan tindakan yang time sensitive yaitu hasilnya baik bila dikerjakan secara segera. Pada keadaan di mana kondisi pasien telah stabil dan diagnosis telah dapat ditetapkan maka pasien dapat dialihkan kepada DPJP bidang keilmuan yang relevan tanpa khawatir adanya penundaan (delay) yang dapat menurunkan kualitas layanan medis kepada pasien.

\section{KESIMPULAN}

Secara umum, dokter spesialis yang dikonsulkan per telepon dokter jaga UGD dan ruangan perihal kegawatdaruratan, saat menjawab konsultasi tersebut telah melakukan perbuatan yang bernilai baik. Selanjutnya jawaban konsultasi per telepon tersebut akan diterjemahkan menjadi instruksi medis.

Benarkah dokter spesialis yang tugas jaga pasti melakukan pelanggaran etik jika sekedar menjawab konsul per telepon untuk pertolongan kegawatdaruratan? Jawaban terhadap pertanyaan ini tidak dapat hitam putih, dan perlu menganalisis situasional serta kategorisasi tindakan pertolongan kegawatdaruratan yang dimaksud. Pada situasi dimana RS memiliki keterbatasan jumlah dokter spesialis dan tidak memungkinkan membuat kebijakan dokter spesialis berdinas jaga standby penuh di luar hari dan jam kerja, maka menjawab konsul per telepon saja tanpa memeriksa langsung pasien saat dikonsulkan tersebut diperbolehkan sepanjang instruksi medis yang diputuskan secara profesional memenuhi kriteria "yakin dapat didelegasikan" dari sisi dokter spesialis yang dikonsulkan, serta "bersedia" dan "mampu" dari sisi dokter jaga yang dilimpahkan pendelegasian tersebut. Analisis dari sisi "mampu" pada dokter jaga, perlu mengikuti kaidah tiga kategorisasi instruksi medis. Implikasi dari tanggungjawab 
etik mengikuti kategorisasi ini.

Jika kategori instruksi medis tersebut dimiliki kewenangan klinisnya oleh dokter jaga secara penuh, maka dokter spesialis boleh hanya memberikan pendapat saja tanpa langsung memeriksa pasien selama situasi kegawatdaruratan pasien secara medis tidak memerlukan perubahan instruksi medis. Pada situasi pendelegasian seperti ini tidak tepat juga dinyatakan sebagai tindakan sub standar (tidak sesuai standar pelayanan medik), karena standar mengacu pada distribusi kompetensi dan kewenangan klinis. Selama sesuai standar kewenangan klinis, maka tindakan pertolongan kegawatdaruratan yang dilakukan dokter jaga yang memiliki kewenangan klinis atas hal tersebut bukanlah tindakan sub standar. Dan untuk memenuhi asas keadilan, menjadi kebijakan yang adil adalah biaya jasa medik atas tindakan kategori pertama ini oleh RS diberikan sepenuhnya kepada dokter jaga tersebut. Dokter spesialis yang dikonsul tetap memiliki panggilan etik kemanusiaan untuk memastikan seluruh instruksi medis tersebut dilaksanakan dengan baik. RS saja mengapresiasi jawaban konsul dari dokter spesialis tersebut dengan jasa medik khusus sebatas untuk menjawab konsul, yang tentu berbeda dengan visite pasien maupun jasa tindakan.

Jika kategori instruksi medis dapat dimiliki kewenangan klinisnya oleh dokter jaga dalam supervisi dokter spesialis, maka SMF spesialisasi di RS tersebut harus membuat mekanisme supervisi yang layak, bertanggungjawab, dan memadai. Disarankan dan dihimbau untuk meminimalisasi instruksi medis yang masuk pada kategori kedua ini dengan cara memindahkan sebanyak-banyaknya ke kategori pertama melalui memberikan perluasan kewenangan klinis pada dokter jaga, atau memperjelas masuk ke kategori ketiga.

Jika kategori instruksi medis hanya dimiliki kewenangan klinisnya oleh dokter spesialis yang dikonsulkan, maka dokter spesialis atau penggantinya sesuai kesepakatan di RS/SMF, memang harus datang memenuhi panggilan kegawatdaruratan, memeriksa, dan melakukan tindakan medis kegawatdaruratan tersebut.

\section{KONFLIK KEPENTINGAN}

Tidak ada konflik kepentingan.

\section{REFERENSI}

1. Majelis Kehormatan Etik Kedokteran Indonesia. Kode etik kedokteran tahun 2012. Jakarta; 2012.

2. Undang-Undang Republik Indonesia nomor 29 tahun 2004 tentang praktik kedokteran. 2004.

3. Peraturan Konsil Kedokteran Indonesia nomor 4 tahun 2011 tentang disiplin profesional dokter dan dokter gigi. 2011.

4. Prawiroharjo P, Librianty N. Tinjauan etika penggunaan media sosial oleh dokter. J Etik Ked Ind. 2017 Oct 11;1(1):31. doi: 10.26880/jeki.v1i1.7.

5. Department of Health and Ageing Australian Government. The Australasian Triage Scale. Dalam: Emergency Triage Education Kit. Canberra: Commonwealth of Australia; p. 9-12.

6. Gilboy N, Tanabe P, Travers D, Rosenau A. Emergency Severity Index (ESI): A triage tool for emergency department care, version 4. Implementation Handbook 2012 Edition. Rockville: Agency for Healthcare Research and Quality; 2011.

7. Sprivulis PC, Da Silva JA, Jacobs IG, Frazer ARL, Jelinek GA. The association between hospital overcrowding and mortality among patients admitted via Western Australian emergency departments. Med J Aust. 2006;184(5):208-12. doi: 10.1016/S08954356(01)00341-9. 
8. Diercks DB, Roe MT, Chen AY, Peacock WF, Kirk JD, Pollack C V., et al. Prolonged emergency department stays of non-ST-segmentelevation myocardial infarction patients are associated with worse adherence to the American College of Cardiology/American Heart Association guidelines for management and increased adverse events. Ann Emerg Med. 2007;50(5):489-96. doi: 10.1016/j. annemergmed.2007.03.033. 

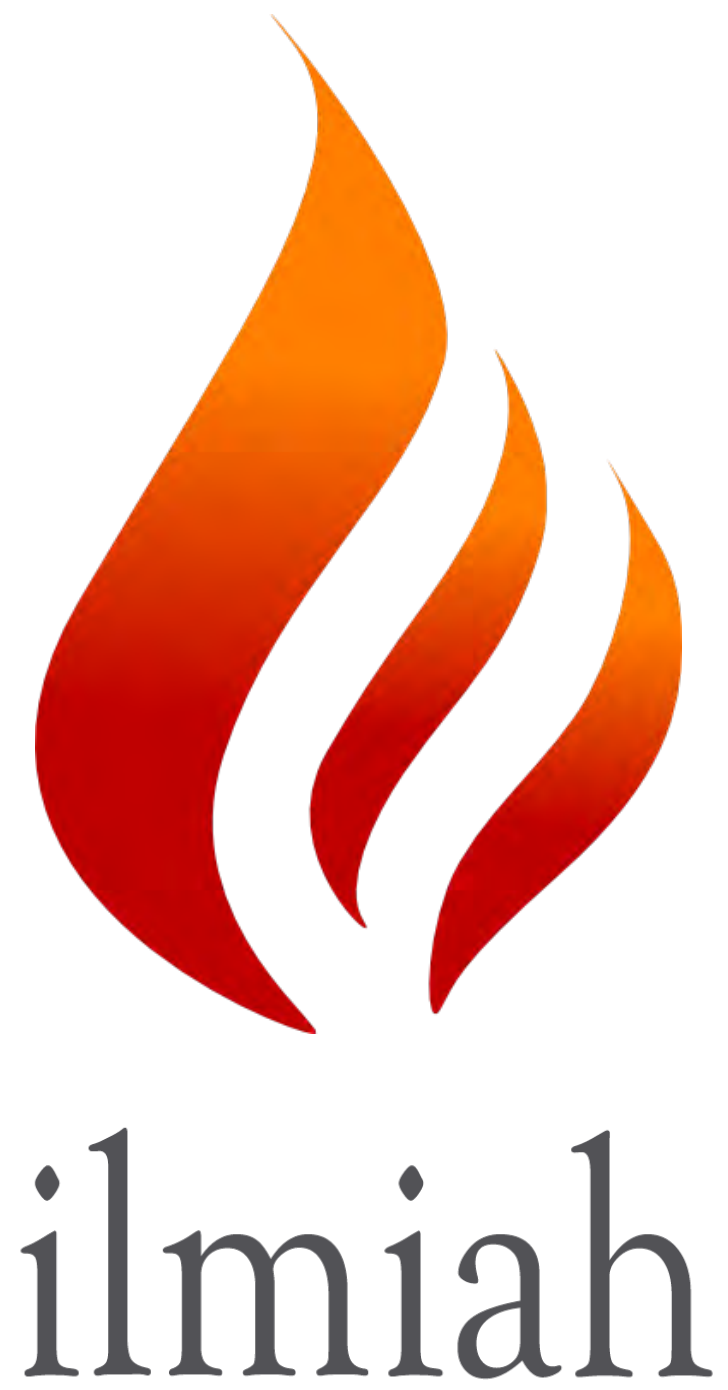

http://www.ilmiah.id your journal portal 